\title{
PRECEDE-PROCEED Model: Predisposing, Reinforcing, and Enabling Factors Affecting the Selection of Birth Attendant in Bondowoso District
}

\author{
Ira Martin Pramiyana'), Uki Retno Budi Hastuti²), Bhisma Murti') \\ 1)Masters Program in Public Health, Universitas Sebelas Maret \\ 2)Department of Obstetrics and Gynecology, Dr. Moewardi Hospital, Surakarta
}

\begin{abstract}
Background: Skilled birth attendant is one of the determinants of maternal and infant mortality. One of the primary causes of maternal mortality in Bondowoso District was the reliance on the traditional birth attendant(TBA). In 2016, the number of birth delivery attended by TBA reached 510 out of 10,326 deliveries. This study aimed to determine the predisposing, reinforcing, and enabling factors affecting the selection of birth attendant in Bondowoso.

Subjects and Method: This was an analytic observational study using case control design. The study was conducted at 5 community health centers in Bondowoso District, East Java,from April to May 2017. A sample of 160 delivering mothers, consisting of 110mothers assisted by skilled birth attendants and 50 mothers assisted by traditional birth attendants, were selected for this study by fixed disease sampling.The dependent variable wasthe selection of birth attendant (skilled birth attendant vs. TBA).The independent variables were age, education, working status, ANC visit, tradition, and family support.The data were collected by a set of questionnaire. Path analysis was employed to analyze data.

Results: Age 20-34 years $(\mathrm{b}=-2.10 ; 95 \% \mathrm{CI}=-3.96$ to $-0.25 ; \mathrm{p}=0.026)$, working outside the house $(b=2.23 ; 95 \% C I=0.84$ to $3.61 ; p=0.002)$, ANC visit $(b=2.71 ; 95 \% C I=0.80$ to $4.62 ; p=0.005)$, good tradition $(b=4.05 ; 95 \% \mathrm{CI}=2.38$ to $5.72 ; \mathrm{p}<0.001)$ increased the likelihood of selecting skill birth attendant. Age20-34 years $(\mathrm{b}=2.54 ; 95 \% \mathrm{CI}=1.24$ to $3.84 ; \mathrm{p}<0.001)$ and maternal education $\geq$ high school $(b=3.69 ; 95 \% \mathrm{CI}=2.47$ to $4.92 ; \mathrm{p}<0.001)$ increased $\mathrm{ANC}$ visit. Maternal education $\geq$ high school $(b=0.74 ; 95 \% \mathrm{CI}=-0.02$ to $1.51 ; \mathrm{p}=0.059)$ increased age. Maternal education $\geq$ high school $(\mathrm{b}=1.39 ; 95 \% \mathrm{CI}=0.63$ to $2.14 ; \mathrm{p}<0.001)$ increased the likelihood of mother working outside the house. Family support ( $b=2.02 ; 95 \% \mathrm{CI}=1.21$ to $2.82 ; \mathrm{p}<0.001)$ increased the likelihood of good tradition.
\end{abstract}

Conclusion:Age 20-34 years, working outside the house, ANC visit, good tradition, directly increase the likelihood of selecting skill birth attendant.

Keywords: selection of birth attendant, predisposing, enabling, reinforcing factors

\section{Correspondence:}

Ira Martin Pramiyana. Masters Program in Public Health, Universitas Sebelas Maret. Jl. Ir. Sutami 36A, Surakarta, Central Java 57126. Email: iramartinpramiyana87@gmail.com.

Mobile: +6282337742697.

\section{BACKGROUND}

In the National Health System (SKN), one indicator of the degree of public health is the Maternal Mortality Rate (MMR). The higher the MMR, it shows that health status can be categorized as poor and has not been successful in improving the highest public health status (Ministry of Health, 2015).
Bondowoso Regency is the highest district with MMR in East Java Province, where MMR increased from 2014, from 17 people to 19 people in 2015. It also experienced an increase in 2016 with AKI 20 people in Bondowoso Regency. One of the causes of the still high MMR in Bondowoso Regency is the existence of traditional birth attend- 
ance assistance by traditional healers. In 2015 the traditional helper healer's birth reached 767 out of 10,219 deliveries and experienced a decline in 2016, namely 510 birth attendants from 10,326 deliveries, but this figure is still relatively high and is a contributor in the case of AKI (Bondowoso Health Office, 2017). Based on the 2012 IDHS data, the Maternal Mortality Rate (MMR) has increased from 228 to 359 per 100,00o live births, so the MDGs target in 2015 has not been achieved, namely reducing the MMR ratio to 102 per 100,000 live births. Whereas currently the SDGs target in 2030 which is a continuation of the MDGs is to reduce the Maternal Mortality Rate to below 70 per 100,00o live births.

One factor that causes high maternal and infant mortality is the ability and skills of childbirth helper. The coverage of childbirth workers in Indonesia based on the results of the 2012 IDHS reached 83\%, this was an increase compared to the results of the 2007 IDHS with a coverage of childbirth helper, namely $73 \%$. The coverage of childbirth helpers is still below the Minimum Service Standards (SPM) in the health sector in 2015, which must reach $85 \%$. This lack of coverage is due to the existence of childbirth assistance by traditional birth attendants who carry out traditional childbirth assistance so that it can endanger the safety of the mother and baby (Ministry of Health, Republic of Indonesia, 2016).

Based on data from the East Java Provincial Health Office (2012), Bondowoso City is still in the districts/ cities in East Java that have an MMR above the provincial rate of 109.50 mothers/ 100,000 live births. One of the causes of the still high MMR in Bondowoso Regency is the existence of traditional birth attendance assistance by traditional healers. In 2014 shaman birth reached 784 out of 8,884 deliveries and experienced a decline in 2015, namely 767 birth attendants from 8,069 deliveries, but this figure was still relatively high and became a contributor in the case of AKI (Bondowoso Health Office, 2017). Therefore, the importance of the 2015-2019 Ministry of Health's Strategic Plan is to establish delivery at health care facilities as one indicator of maternal health efforts.

According to Green and Kreuter (2005), there are three factors in the use of health services including predisposing factors (knowledge, attitudes, beliefs, values, socio-economic, age, sex and perception related to individual motivation), the enabling factors are ability and resources needed to do something (cost, distance traveled, availability of transportation, service time and skills of health personnel) as well as reinforcing factors are factors that strengthen the occurrence of actions (community leaders, families). The research on the behavior of the selection of delivery assistance is the result of research by Gitimu et al., (2015) suggesting that the level of maternal education, the level of education of husbands, ANC visits and distance to health facilities for the selection of labor personnel have a significant relationship to the selection of birth attendants.

The East Java Health Service launched the GEBRAK Joint Movement, this program was carried out starting in 2013 by providing assistance to high-risk pregnant women for 10 months, followed from pregnancy to postpartum involving PKK cadres and midwifery academy students in East Java. This program is expected to detect early complications in pregnant women so that prevention and early treatment by health personnel can be carried out immediately when they give birth when they have decided to be handled by health personnel. 
So far, the Bondowoso Health Office Report is limited to the number of shaman births, while the causes of traditional birth attendance have not been revealed further, so it is necessary to examine what factors influence the selection of birth attendants in Bondowoso Regency in 2016.

\section{SUBJECTS AND METHOD \\ 1. Study Design}

This was an analytic observational study with a case control design. The study was carried out in 5 community health centers in Bondowoso, East Java, from March to May 2017.

\section{Population andSamples}

The target population in this study were all mothers who had delivery assistance in the working area of Pujer, Tlogosari, Pakem, Botolinggo, and Cermee Health Centers, Bondowoso District in 2016. The target population in this study were all mothers who had delivery assistance by traditional healer and helper in the working area of Pujer Health Center, Tlogosari Health Center, Pakem Health Center, Botolinggo Health Center, and Cermee Health Center Bondowoso District in 2016. Samples in quantitative research were 160 subjects. The sampling technique that will be used in quantitative research is fixed disease sampling which is to ensure sufficient number of research subjects in diseased (case) and non-diseased (control) groups to benefit researchers when the prevalence of the studied disease is low (Murti, 2013)

The dependent variable was the selection of birth attendant. The independent variables are age, education, occupation, ANC visits, traditions, distance to health services, delivery costs, and husband / family support.

\section{Operational definition of variables}

Age was defined as maternal age at the time of giving birth to the last child. Education was the last level of formal education / school that has been completed by the mother and marked by the ownership of a diploma. Maternal job was a routine activity carried out by mothers both at home and outside the house to earn income.

ANC visit was the frequency of the mother when checking her pregnancy in a health personnel, at least $4 \mathrm{x}$ during pregnancy.

Tradition was a habit that develops in society and applies for generations through written and oral information, and tradition becomes part of culture. The distance to health care was the distance the mother must take to get delivery assistance services. The cost of delivery is the amount of money spent by the mother to pay for childbirth assistance. Husband/ family support is a mother's statement about the presence or absence of support from her husband or family during pregnancy and in choosing a birth attendant.

The choice of birth attendant was a decision taken by the mother about the person chosen at the time of giving birth to the last child.

The data were collected by questionnaire and analyzed by path analysis run on Stata 13.

\section{Reliability Test}

Based on the results of item-total correlation reliability test, it was found that in measuring the variables of age, education, occupation, ANC visits, traditions, distance to health services, delivery costs, husband / family support and selection of birth attendant with counts count $\geq 0.20$, and Cronbach's Alpha $\geq 0.70$, so all questions are reliable. The results of the reliability test questionnaire can be seen in Table 1.

Data analysis was conducted using bivariate analysis with SPSS version 22. Multivariate analysis was carried out using STATA path analysis. 
Journal of Health Promotion and Behavior (2017), 2(2): 161-174

https://doi.org/10.26911/thejhpb.2016.02.02.06

Table 1. Reliability test results

\begin{tabular}{lcc}
\hline \multicolumn{1}{c}{ Variable } & Item Total Correlation (r) & Alpha Cronbach \\
\hline ANC Visit & $\geq 0.50$ & 0.74 \\
Tradition & $\geq 0.51$ & 0.94 \\
Distance to health services & $\geq 0.49$ & 0.93 \\
Delivery costs & $\geq 0.53$ & 0.86 \\
Support of husband / family & $\geq 0.47$ & 0.92 \\
Selection of childbirth helper & $\geq 0.38$ & 0.76 \\
\hline
\end{tabular}

$\frac{\text { RESULTS }}{\text { A.Univariate Analysis }}$

The results of the study were 110 cases of maternal subjects with childbirth assistance by a traditional helper and a control group of 50 subjects of mothers who had childbirth assistance by midwives.

Table 2 shows that age $20-34$ dominates for about $65.1 \%$ in the case group while in the control group $72.5 \%$, maternal education in the low category is $89.9 \%$ in the case group and $76.5 \%$ in maternal education is high in the control group, maternal work in the working category the house dominated in the case and control group of $85.3 \%$ and $52.9 \%$, non-routine ANC visits were $80.7 \%$ in the case group and $76.5 \%$ routine $\mathrm{ANC}$ visits in the control group.

Table 2. The Characteristics of study subjects

\begin{tabular}{|c|c|c|c|c|}
\hline \multirow{2}{*}{ Characteristics } & \multicolumn{2}{|c|}{ Case } & \multicolumn{2}{|c|}{ Control } \\
\hline & $\mathbf{N}$ & $(\%)$ & $\mathbf{N}$ & $(\%)$ \\
\hline \multicolumn{5}{|l|}{ Maternal age (year) } \\
\hline$<20$ atau $\geq 35$ & 38 & 34.9 & 14 & $27 \cdot 5$ \\
\hline \multicolumn{5}{|l|}{ Maternal education } \\
\hline Low $(<$ SHS $)$ & 98 & 89.9 & 12 & 23.5 \\
\hline $\operatorname{High}(\geq \mathrm{SHS})$ & 11 & 10.1 & 39 & 76.5 \\
\hline \multicolumn{5}{|l|}{ Maternal occupation } \\
\hline Working at home & 93 & $85 \cdot 3$ & 27 & 52.9 \\
\hline Working outside & 16 & 14.7 & 24 & 47.1 \\
\hline \multicolumn{5}{|l|}{ ANC visit } \\
\hline irregular ( $<4$ times) & 88 & 80.7 & 12 & 23.5 \\
\hline regular ( $\geq 4$ times) & 21 & 19.3 & 39 & 76.5 \\
\hline \multicolumn{5}{|l|}{ Tradition } \\
\hline Traditional & 104 & 95.4 & 16 & 31.4 \\
\hline Not traditional & 5 & 4.6 & 35 & 68.6 \\
\hline \multicolumn{5}{|l|}{ Distance to health services } \\
\hline Far $(\geq 2 \mathrm{~km})$ & 63 & 57.8 & 15 & 29.4 \\
\hline Close $(<2 \mathrm{~km})$ & 46 & 42.2 & 36 & 70.6 \\
\hline \multicolumn{5}{|l|}{ Birth delivery costs } \\
\hline Low $(<\mathrm{Rp} 600,000)$ & 20 & 18.3 & 28 & 54.9 \\
\hline High $(\geq \operatorname{Rp} 600,000)$ & 89 & 81.7 & 23 & 45.1 \\
\hline \multicolumn{5}{|c|}{ Support of husband / family } \\
\hline Low & 88 & 80.7 & 12 & 23.5 \\
\hline High & 21 & 19.3 & 39 & 76.5 \\
\hline
\end{tabular}

The support for tradition (traditional) was $95.4 \%$ in the case group and $68.6 \%$ did not support the tradition (not traditional) in the control group, access to health services with 
a distance of $\geq 2 \mathrm{~km}$ in the case group $57.8 \%$ and $70.6 \%$ with a distance of $<2 \mathrm{~km}$ in the control group, the high cost of delivery in the case group was $81.7 \%$ and in the control group $54.9 \%$ with low delivery costs, and husband / family support for about $80.7 \%$ low support in the case group and $76.5 \%$ high support in the control group.

\section{B. Bivariate Analysis}

Bivariate analysis explains the effect of one independent variable on one dependent variable using the chi-square test, with a 95\% confidence level.

Table 3 shows that maternal education $\geq$ senior high school $(\mathrm{OR}=28.95 ; 95 \% \mathrm{CI}=$ 11.79 to $71.10 ; \mathrm{p}<0.001)$; mother working outside the house $(\mathrm{OR}=5.16 ; 95 \% \mathrm{CI}=2.40$ to 11.09; $\mathrm{p}<0.001$ ); ANC visit $\geq 4$ times Table 3. Bivariate analysis of study variables

\begin{tabular}{lcccc}
\hline \multirow{2}{*}{ Independent Variable } & \multirow{2}{*}{ OR } & \multicolumn{2}{c}{ 95\% CI } & \multirow{2}{*}{ p } \\
\cline { 3 - 4 } & & Lower Limit & Upper Limit & \\
\hline Maternal age & 1.41 & 0.68 & 2.93 & 0.351 \\
Maternal education & 28.95 & 11.79 & 71.10 & $<0.001$ \\
Maternal occupation & 5.16 & 2.40 & 11.09 & $<0.001$ \\
ANC Visit & 13.61 & 6.10 & 30.40 & $<0.001$ \\
Tradition & 45.50 & 15.53 & 133.28 & $<0.001$ \\
Distance to health services & 3.28 & 1.61 & 6.70 & 0.001 \\
Birth delivery cost & 5.41 & 2.59 & 11.29 & $<0.001$ \\
Support of family and husband & 13.61 & 6.10 & 30.40 & $<0.001$ \\
\hline
\end{tabular}

Table 4 shows that pregnant women with ages 20-34 years have logodd to choose midwives as birth attendants 2.10 points lower than pregnant women with age $<20$ years or $\geq 35$ years $(\mathrm{b}=-2.10$; $95 \% \mathrm{CI}=$ -3.96 to $-0.25 ; \mathrm{p}=0.026)$. Mothers who work outside the home have a logodd to choose midwives as birth attendants 2.23 points higher than mothers who work at home $(\mathrm{b}=2.23 ; 95 \% \mathrm{CI}=0.84$ to $3.61 ; \mathrm{p}=$ 0.002). Pregnant women who routinely have an ANC examination $\geq 4$ times have a logodd to choose a midwife as a delivery helper 2.71 points higher than a pregnant woman who does not routinely do an ANC examination $(b=2.71 ; 95 \% \mathrm{CI}=0.80$ to
$(\mathrm{OR}=13.61 ; 95 \% \mathrm{CI}=6.10$ to $30.40 ; \mathrm{p}$ $<0.001)$; low support for tradition ( $\mathrm{OR}=$ 45.50; $95 \% \mathrm{CI}=15.53$ to $133.28 ; \mathrm{p}<0.001)$; the distance to health services $<2 \mathrm{~km}(\mathrm{OR}=$ 45.50; $95 \% \mathrm{CI}=15.53$ to $133.28 ; \mathrm{p}=0.001)$; delivery costs $<\mathrm{Rp} 600,000(\mathrm{OR}=5.41 ; 95 \%$ $\mathrm{CI}=2.59$ to $11.29 ; \mathrm{p}<0.001) ;$ strong husband/ family support $(\mathrm{OR}=13.61$; CI $95 \%=6.10$ to $30.40 ; \mathrm{p}<0.001)$ increased the likelihood of maternal choice to effect on increasing the selection of birth attendants. These results are statistically significant. The results of bivariate analysis showed that there was no relationship between maternal age $(\mathrm{OR}=1.41 ; 95 \% \mathrm{CI}=$ 0.68 to $2.93 ; \mathrm{p}=0.351$ ) on the selection of birth attendants.
4.62; $\mathrm{p}=0.005)$. Mothers who do not support the tradition (not traditional) have logodd to choose midwives as birth attendants 4.05 points higher than mothers who support traditional (traditional) traditions (b = 4.05; 95\% CI = 2.38 to 5.72; $\mathrm{p}<0.001$ ).

Routine ANC examination is influenced by age, occupation and maternal education. Pregnant women aged 20-34 years have logodd to perform routine ANC examinations 2.54 points higher than mothers with age $<20$ years or $\geq 35$ years $(b=2.54$; CI $95 \%=1.24$ to 3.84 ; p <0.001). Mothers who work outside the homehave a logodd to perform routine ANC examinations 0.51 points lower than mothers who worked inside the house $(\mathrm{b}=-$ $0.51 ; 95 \% \mathrm{CI}=-1.65$ to $0.63 ; \mathrm{p}=0.380$ ). 
Journal of Health Promotion and Behavior (2017), 2(2): 161-174

https://doi.org/10.26911/thejhpb.2016.02.02.06

Mothers who were highly educated had logodd to perform routine ANC examinations education $(\mathrm{b}=3.69 ; 95 \% \mathrm{CI}=2.47$ to $4.92 ; \mathrm{p}$ 3.69 points higher than those with lower $<0.001)$.

Table 4. Path analysis results

\begin{tabular}{|c|c|c|c|c|c|c|}
\hline \multirow[b]{2}{*}{$\begin{array}{c}\text { Independent } \\
\text { Variable }\end{array}$} & \multirow{2}{*}{\multicolumn{2}{|c|}{$\begin{array}{l}\text { Dependent } \\
\text { Variable }\end{array}$}} & \multirow[b]{2}{*}{$\mathbf{b}$} & \multicolumn{2}{|c|}{ 95\% CI } & \multirow[t]{2}{*}{$\mathbf{p}$} \\
\hline & & & & $\begin{array}{l}\text { Lower } \\
\text { Limit }\end{array}$ & $\begin{array}{l}\text { Upper } \\
\text { Limit }\end{array}$ & \\
\hline \multicolumn{7}{|l|}{ Direct Effect } \\
\hline Birth delivery in & $\leftarrow$ & Age 20-34 years & -2.10 & -3.96 & -0.25 & 0.026 \\
\hline midwife & $\leftarrow$ & $\begin{array}{l}\text { Mothers working } \\
\text { outside }\end{array}$ & 2.23 & 0.84 & 3.61 & 0.002 \\
\hline & $\leftarrow$ & $\begin{array}{l}\text { Regular examination } \\
\text { of ANC } \geq 4 \text { kali }\end{array}$ & 2.71 & 0.80 & 4.62 & 0.005 \\
\hline Indirect $\mathbf{E}$ & $\leftarrow$ & Not traditional & 4.05 & 2.38 & $5 \cdot 72$ & $<0.001$ \\
\hline $\begin{array}{l}\text { Regular examination of } \\
\text { ANC } \geq 4 \text { times }\end{array}$ & $\leftarrow$ & Age 20-34 years & 2.54 & 1.24 & 3.84 & $<0.001$ \\
\hline $\begin{array}{l}\text { Regular examination of } \\
\text { ANC } \geq 4 \text { times }\end{array}$ & $\leftarrow$ & $\begin{array}{l}\text { Maternal education } \\
\geq \text { SHS }\end{array}$ & 3.69 & 2.47 & 4.92 & $<0.001$ \\
\hline Age 20-34 years & $\leftarrow$ & $\begin{array}{l}\text { Maternal education } \\
\geq \text { SHS }\end{array}$ & 0.74 & -0.02 & 1.51 & 0.059 \\
\hline $\begin{array}{l}\text { Mothers working } \\
\text { outside }\end{array}$ & $\leftarrow$ & $\begin{array}{l}\text { Maternal education } \\
\geq \text { SHS }\end{array}$ & 1.39 & 0.63 & 2.14 & $<0.001$ \\
\hline $\begin{array}{l}\text { Not supporting the } \\
\text { tradition (not } \\
\text { traditional) }\end{array}$ & $\leftarrow$ & $\begin{array}{l}\text { High husband and } \\
\text { family support }\end{array}$ & 2.02 & 1.21 & 2.82 & $<0.001$ \\
\hline
\end{tabular}

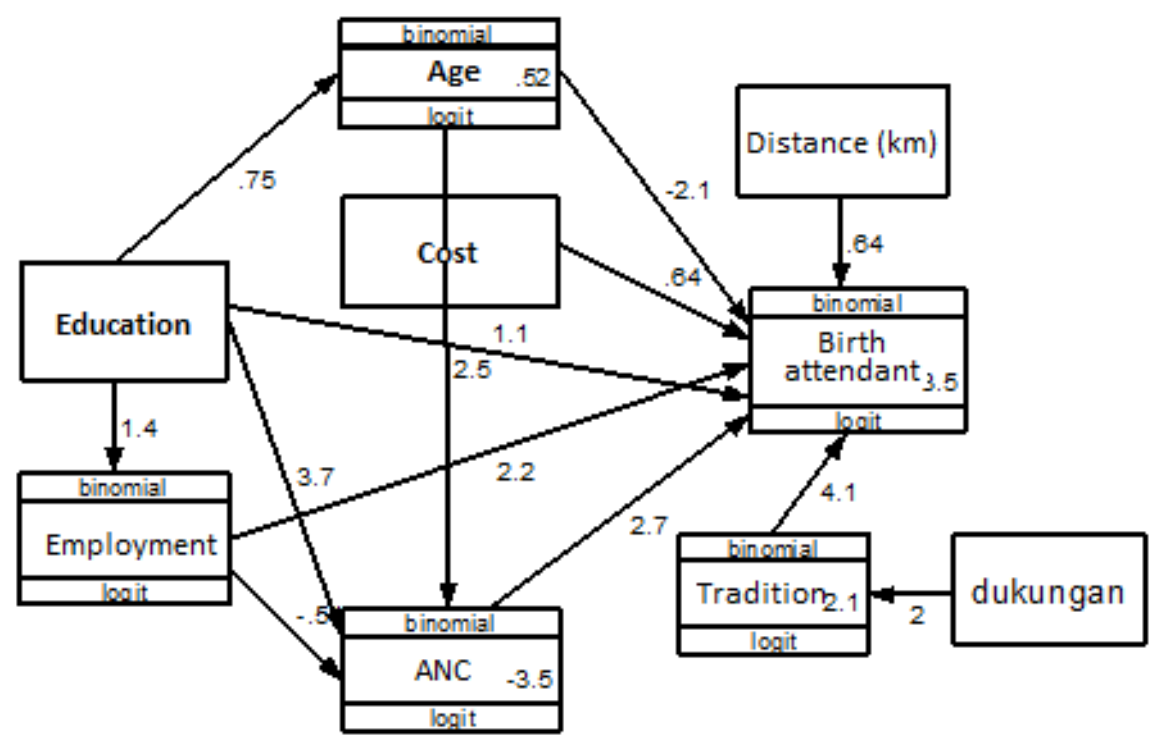

FIgure1. Structural Model with Estimate

Maternal work and age are influenced by maternal education. Mothers who were highly educated had a logodd to choose to work outside the home 1.39 points higher than mothers with low education $(b=1.39$; 95\% $\mathrm{CI}=0.63$ to $2.14 ; \mathrm{p}<0.001)$. Mothers with high education had logodd to enter the category 20-34 years 0.74 points higher than 
mothers with low education $(\mathrm{b}=0.74 ; 95 \%$ $\mathrm{CI}=-0.02$ to $1.51 ; \mathrm{p}=0.059)$. Mothers with high husband / family support have a logodd to not support tradition (not traditional) 2.02 points higher than mothers with low husband / family support $(\mathrm{b}=2.02 ; 95 \% \mathrm{CI}=1.21$ to 2.82; $\mathrm{p}<0.001)$.

\section{DISCUSSIONS}

\section{The Effect of Age on the Selection of Birth Attendant}

The result of analysis showed that there was an effect of maternal age on the selection of birth attendant which was statistically significant $(\mathrm{OR}=1.41 ; \mathrm{b}=-2.10$; $95 \% \mathrm{CI}=-3.96$ to $-0.25 ; \mathrm{p}=0.026)$. Age was an individual variable. Basically, the enhancement of age and maturity would make someone to absorb more information that would affect the mothers in the selection of birth attendant. Maternal age was considered very influential on the reproductive process, the optimal age for the process of pregnancy and birth delivery was 20 to $<35$ years old (WHO, 2016). Maternal mortality in pregnant women and labor below 20 years old was 2-5 times higher than maternal mortality at the age of 20-30 years old (Prawirohardjo, 1991 in Meylanie, 2010).

The result of this study was in line with a study done by Bashar (2012) which revealed that there was a negative relationship between age and the selection of birth attendant. This study was also supported by Masita et al., (2014) which stated that there was no meaningful relationship between age and the selection of birth attendant.

The enhancement of a person's age would increase the technical and psychological maturity as well. In addition, age can described a mother's experience in carrying out the previous labor process. The more mature the mother's age, the higher the possibility to make good decisions, including the decision to choose a birth attendant. But in this situation, it can also be influenced by the level of education, knowledge, and family support.

The results of this study indicated that older women tend not to use the help of midwives in the delivery process. This was due to the increasing age of a woman, because women would have more experiences about the process of pregnancy and labor, thus affecting them to not use medical personnel (midwives), but rather to choose non-medical personnel (indigenous medical practitioner) at the time of delivery.

\section{The Effect of Employment on the Selection of Birth Attendant}

The result of analysis showed that there wasa direct effect of maternal employment on the selection of birth attendant which was statistically significant. The result of this study was in line with a theory ofGreen andKreuter (2005) which stated that a job was in the pre-disposition factor which could facilitate or predispose the occurrence of behavior in the individual and society.

The score in this study was $(b=2.23$; $95 \% \mathrm{CI}=0.84$ to $3.61 ; \mathrm{p}=0.002)$. The result of this study was in line with a study done by Masita et al., (2014) which showed that there was a relationship between maternal employment and the selection of birth attendant $(\mathrm{p}=0.001)$. This study was also in accordance with a study done by Inyang (2015) which showed that there was a significant and direct effect of maternal employment and the selection of birth attendant.

Working mothers have better access to health information. This was because mothers who work got more information or counseling about birth attendant that could be obtained through colleagues, electronics, seminars, and others. Mothers with broad access to information have a greater chance 
Journal of Health Promotion and Behavior (2017), 2(2): 161-174

https://doi.org/10.26911/thejhpb.2016.02.02.06

of utilizing health personnel as birth attendants. The environment and friends around the working mothers have an influence on the formation of opinions and beliefs, because the presence of contacts and interactions would increase the maternal knowledge which ultimately affected the attitude and behavior that would be chosen.

Family income was considered to affect this factor, where working mothers tend to have adequate family income, especially to fulfill the rates of birth delivery services by midwives or other medical personnel, thus ignoring alternatives to choose anindigenous medical practitioner. This indicated that families with low income would prefer to use traditional birth attendants in childbirth assistance, this was because the fees or cost imposed by indigenous medical practitioner tend to be much cheaper than the rates by midwives or other medical personnel.

\section{The Effect of Education on the Selection of Birth Attendant}

The result of analysis showed that there was an effect of education on the selection of birth attendant which was statistically insignificant $(b=1.10 ; 95 \% \mathrm{CI}=-0.29$ to $2.51 ; p=0.122)$. Maternal education affected the way of thinking, action and decisionmaking processes in using health services. This was also supported by the opinion that the higher the maternal education, the better the knowledge about health, they tend to pay more attention to the health of themselves and their families and were able to make decisions regarding their health, for example in determining where they would give birth (Gitimu et al., 2015).

The result of this study was in line with a study done by Tadese and Ali (2014) which stated thatthere was a relationship between maternal education and the selection of birth attendant $(\mathrm{AOR}=5.3 ; 95 \% \mathrm{CI}=$ 2.9 to 9.8), it was stated that highly- educated mothers were 5.3 times more likely to choose midwives (health personnel) in conducting labor.

This study was also in accordance with a study done by Arief (2012) which showed that there was there was a differrence in the proportion of the incidence of labor selection at health facileties between highly-educated mothers and mothers with low education with $\mathrm{OR}=4.36$. This mean that mothers who were highly educated were 4.36 times more likely to choose labor in health facilities compared to mothers with low education.

The higher a person's education, the higher the level of understanding, it would be easier for her/him to receive new information that was applied in life. The low level of education could lead to difficulties in absorbing information, whereas someone who has a higher level of education would be more open in accepting new ideas. This could occur because low maternal education affected the use of access to health facilities. Highly-educated mothers tend to have better thinking insight and tend to be able to make wiser decisions about their own health compared to mothers with low education.

Mothers who were highly educated would have better knowledge, especially regarding the best birth attendant for themselves. Therefore, the level of education could affect maternal behaviors, one of them was in selecting the best birth attendant, which was assisted by health personnel.

\section{The Effect of ANC Visit on the Selection of Birth Attendant}

The result of analysis showed that there was a direct effect of ANC visit on the selection of birth attendant which was statistically significant. The existence of integrated ANC visits and services was expected that the labor would be conducted at health 
care facilities with skilled health personnels and the birth delivery was carried out in accordance with the standards of Normal Childbirth Care (NCC) (Ministry of Health RI, 2014).

The interaction between mothers and health personnels during the antenatal care period could build maternal self-confidence and trust in health personnels, and this was a good basis in selecting birth attendants.

The result of this study was in line with a study done byArmstrong (2011) which concluded that there was a significant relationship between ANC visit and the selection of birth attendant. Mothers with routine ANC visits which were more than 4 times have the opportunity to get birth assistance by health personnels compared to mothers who did not routinely conduct ANC visits.

This study was also supported by a study done by Tadese and Ali (2014) which stated thatthere was a significant relationship between ANC visit during the last pregnancy and the selection of birth attendant.

This was because mothers who routinely make ANC visits could get many benefits, one of them was the provision of health education and information regarding the importance of health personnels' assistance at the time of delivery. In addition, mothers also obtained knowledge about the risks and danger signs of pregnancy and labor, so that if the mother was included in these risk factors, the mother would tend to choose health personnels in the labor process. The fact was that mothers with regular ANC visits got a lot of health information and information about the benefits of labor assistance by health personnels.

This was because at each ANC visit, health counseling was conducted as well as counseling guidance by health personnels according to maternal needs. Therefore, mothers who have knowledge about risk factors for pregnancy and labor were more likely to give birth with the help of health personnels than mothers who have lack of knowledge.

According to researchers, the results of several high-level antenatal examinations illustrated that pregnant women were aware of the importance of prenatal care, but there were some effects of family habits that still believed to give birth at indigenous medical practitioner, so even though pregnant women were routinely checked their pregnancies, they still choose indigenous medical practitioner as birth attendants. Based on the fact above, an active role of health personnels was needed in promoting the importance of labor by health personnels and partnerships with traditional healers and cadres who still need to be maximized.

\section{The Effect of Tradition on the Selection of Birth Attendant}

The result of analysis showed that there was a direct effect of tradition on the selection of birth attendant which was statistically significant $(b=4.05$; CI $95 \%=$ 2.38 up to $5.72 ; \mathrm{p}<0.001)$. Tradition was something that has been done for a long time and became part of the community and culture group's life, where the most basic thing of tradition was the information that was passed on from generation to generation both written and (often) verbally, because without this action, a tradition could became extinct (Inyang, 2015).

The result of this study was in line with a study done by Armstrong (2011) which stated that there was a relationship between tradition and the selection of birth attendant. Statistically with the score of $\mathrm{OR}=24$, this mean that mothers who selected indigenous medical practitioner were 24 times more likely to be mothers with lack of tradition support than mothers 
Journal of Health Promotion and Behavior (2017), 2(2): 161-174

https://doi.org/10.26911/thejhpb.2016.02.02.06

who have tradition supports. This study was also supported by a study done byFerdinand et al., (2014) which stated that there was a significant effect of tradition factor and the selection of birth attendant. The probability of mothers with supporting tradition factors was $96.47 \%$ would choose an indigenous medical practitioner, while the probability of a mother with a lack of tradition factor was $39.98 \%$ to choose anindigenous medical practitioner as a helper of birth delivery. This was due to the existence of several regions in Southern Nigeria that were isolated and relatively difficult to be reached by health facilities and health personnels, therefore, this opened up the opportunities for traditional healers to take medical actions, especially delivery assistance..

Tradition has a direct effect on the selection of birth attendants, because the general conditions of pregnancy and childbirth were interpreted differently according to different cultures and traditions. If in the beginning of pregnancy care to postpartum could be done at home with the help of an indigenous medical practitioner, then it was most likely that the mother would choose a traditional healer as her birth attendant.

Previous perceptions and experience of labor affected the mother in choosing a birth attendant, because through a positive perception, there could also be positive perceptions. If the mother has a positive experience, it would also affect the positive perception of the birth attendant. In addition, this would also foster a permanent and civilized thinking for the community to use the indigenous medical practitioner as a birth attendant. The existence of labor assistance by traditional birth attendants showed that not all communities were ready to implement behavioral changes, socio-cultural influences and lack of information and the ability to receive and absorb the information.

\section{The Effect of Distance to Health Services on the Selection of Birth Attendant}

The result of analysis showed that there was an effect of distance to health services on the selection of birth attendant which was statistically insignificant $(b=0.63 ; 95 \%$ $\mathrm{CI}=-0.66$ to $1.94 ; \mathrm{p}=0.337)$. Physical access could be the reason to get a place of birth delivery in health services including a place of birth with health personnels. Physical access could be calculated from travel time, distance traveled, type of transportation, and conditions in health services such as type of service, availability of health personnels and open hours. The location of services that was not strategic/ difficult to reach lead to a lack of access for pregnant women who would give birth in health services (Basic Health Research, 2013).

The result of this study was in accordance with a study done byTadese and Ali (2014) which stated that there was a relationship between distance and travel time of maternal residence with the selection of birth attendant, it was stated that mothers with close distance to health services were 14.65 times to choose health personnel as birth attendant compared to mothers with far distance to health facilities.

Significance of distance and transportation also complemented the utilization of birth attendant. This could be explained by the enhancement of distance from health facilities, transportation costs, and the amount of time spent during the trip to health facilities and the possibility of low health information exposure. Media programs for health promotion, information and knowledge about modern health care facilities were centered on mothers who have access and distance to accessible 
health facilities, therefore, the mothers who were far from health facilities were still affected by traditional practices such as delivery assistance by traditional birth attendants.

\section{The Effect of Labor Costs on the Selection of Birth Attendant}

The result of analysis showed that there was a direct effect of labor costs on the selection of birth attendant which was statistically insignificant $(\mathrm{b}=0.63$; $95 \% \mathrm{CI}=$ -0.89 to $2.16 ; \mathrm{p}=0.415)$. The amount of costs a mother must pay for labor became an important consideration for the mother in choosing her birth attendant. Moreover, if the mothers were supported by an adequate socio-economic condition, a mother would prefer to give birth to professional health personnels such as doctors and midwives compared to giving birth to an indigenous medical practitioner. One of the reasons to choose indigenous medical practitioner as birth attendant was because the process of payment in indigenous medical practitionerservices was easier, and it was not expensive. In this case, childbirth assistance by health personnel was still considered expensive, for example health facilities such as urban hospitals still have to provide advance payment to guarantee the care of mothers who would give birth.

The result of this study was in accordance with a study doneby Sumintardi (2012) which stated that there was no significant relationship between labor costs and the selection of birth attendant, and the result of statistic test was $p=2.215$. This was because the costs of birth assistance by indigenous medical practitioner and midwive was the same and were considered inexpensive or affordable by the community.

There was also an assumptions in the community that doing a labor in health personnels cost quite expensive, therefore, mothers prefer to give birth at home and choose to be helped by indigenous medical practitionerbecause of the cost was cheaper and the payment could be paid in installments, in addition, it has become a hereditary habit. The insignificant relationship between costs and selection of birth attendant was also caused by socio-culture. Although the mother stated that the delivery costs to the shaman were cheaper, but if the costs of dukun were calculated, added by the pament of equipment and also maternal and infant care for up to 40 days during labor, the costs were almost the same as the cost of delivery to the midwife, but the payment mechanism could be carried out gradually so that it helped the mother.

The existence of an insurance of labor financing from the government in the form of BPJS helped the mothers to pay the delivery cost, because mothers who gave birth in health personnels did not have to pay. This was in accordance with the statement of Nakambale et al., (2014) which stated that by removing the cost of birth delivery in Northern Zambia, it was noted that the impact on increasing demand for health services and childbirth assistance by traditional birth attendants was reported to have decreased. Therefore, to reduce the Maternal Mortality Rate, the Government and the Ministry of Health have initiated and sought free deliveries through the BPJS (Social Security Organizing Agency) program.

But in the implementation, not all of the mothers used the BPJS properly, especially in getting free delivery fees. This was because of the lack of understanding that nowadays, the cost of birth delivery was free, there was a lack of information about how to use the BPJS or for other reasons. Changes in perceptions and attitudes were needed for the community, 
especially those who considered that the cost of service in a midwife or health personnel was considered expensive.

\section{The Effect of Husband/Family Support on the Selection of Birth Attendant}

The result of analysis showed that there was an indirect effect of husband/family support on the selection of birth attendant $(\mathrm{b}=2.02 ; 95 \% \mathrm{CI}=1.21$ to $2.82 ; \mathrm{p}<0.001)$.

The roles and responsibilities of husband and family in reproductive health greatly affected women's health. Important decisions such as the birth attendant, most were determined unilaterally by husband or family. Husband's support in labor process such as ensuring safe delivery by health personnel, providing funds, equipment and transportation needed, accompanying during the labor process, and supporting referral efforts (if needed) were very necessary to support a safe labor process (Basic Health Research, 2013).

The result of this study was in accordance with a study doneby Masita et al., (2014) which stated that there was a significant relationship betweem family support and the selection of birth attendant, and the statistic resultwas $\mathrm{p}=0.202$.

This was due to the existence of a patriarchal system in which men or husbands were the heads of households who made major decisions in the family, especially in rural areas. The influence of the family determined the mothers who were going to give birth for the selection of places and birth attendant. Mother as a woman did not dare to make decisions because of the low status of women in the family, therefore, they were not bracve enough to act and were more independent in deciding what was best for themselves, including their health. In addition, the dominance of parents could have greater influence than husbands.
Decision making was mostly done by parents (mothers) because of the belief that mothers have passed down for generations that delivery was carried out by traditional birth attendants and mothers were always encouraged to go to traditional healers compared to health personnels (midwives). The results of further analysis found that tradition was a confounding of the relationship between husband/family support for the selection of birth attendants. This mean that the support of husband/ family would affect the adopted and conducted tradition which was ultimately followed by the selection of birth attendants.

The choice of birth attendants was affected by age, employment, ANC visits, and traditions. ANC visits were influenced by maternal age and education. Maternal age and employment were affected by education. Tradition was affected by family support.

\section{REFERENCES}

Arief M (2012). Determinan Pemilihan Persalinan di Fasilitas Kesehatan (Analisis Data Riset Kesehatan Dasar Tahun 2010).FKM-UI.Depok.

Armstrong A (2011).The Impact of Traditions and Traditional Birth Attendants on Maternal Mortality: A Case Study of Nyakayojo sub-Country Mbarara District Uganda.University of Colorado Boulder.

Bashar A (2012). Determinants of The Use of Skilled Birth Attendants at Delivery by Pregnant Women in Bangladesh, Master Student Department of Public Health and Clinical Medicine. Umea University Sweden.

Cunningham F, Leveno K, Bloom S, Spong C, Dashe J, Hoffman B, Casey B, Sheffield J (2010). Obstetri Williams 23rd ed. McGraw-Hill Companies. Inc, USA. 
Dinas Kesehatan Provinsi Jawa Timur (2012). Angka Kematian Ibu Tahun 2014.

Dinas Kesehatan Kabupaten Bondowoso (2017). Data Laporan KIA Kabupaten Bondowoso 2015 dan 2016.

Ferdinand O, Geoffrey N, Christopher E (2014). Journal of Public Health Epidemiology: Traditional Birth Attendants and Women's Health Practices: A Case Study of Patani in Southern Nigeria, 6(8): 252-261, ISSN 20069723, Department of Public Health Technology Federal University of Technology.

Fertman C, Allenswort D (2010).Health Promotion Programs from Theory to Practice, Jossey-Bass, San Francisco.

Gitimu A, Herr C, Oruko H, Karijo E, Gichuki R, Ofware P, Lakati A, Nyagero J (2015). Determinants Of Use Of Skilled Birth Attendant At Delivery In Makueni Kenya: A Cross Sectional Study, BMC Pregnancy and Childbirth 15:9.

Green L, Kreuter M (2005). Health program planning: An educational and ecological approach with PowerWeb bind-in card.McGraw-Hill. New York.

Inyang M, Anucha O (2015). IOSR Journal of Dental and Medical Sciences: Traditional Birth Attendants and Maternal Mortality, Department of Human Kinetics and Health Education Faculty of Education 14(2):21-26.

Kementrian Kesehatan RI (2013). Kementerian RI Pokok-Pokok Hasil Riskesdas Indonesia Tahun 2013.Badan Penelitian dan Pengembangan Kesehatan.

(2013). Keputusan Menteri Kesehatan Republik Indonesia Nomor 369/MENKES/SK/III/2007 Tentang Standar Profesi Bidan dan Peraturan
Menteri Kesehatan Republik Indonesia Nomor 97 Tahun 2013.Jakarta.

(2015). Rencana Strategis Kementerian Kesehatan Tahun 2015-2019. Jakarta.

(2015). Profil Kesehatan Indonesia Tahun 2014. Kementerian Kesehatan RI. Jakarta.

(2016). Profil Kesehatan Indonesia Tahun 2015. Jakarta.

Masita, Novita H, Puspita E (2014). Pemilihan Penolong Persalinan. Jurnal Health Quality 5(1): 1-66. Kemenkes Jakarta.

Meylanie (2010). Faktor-faktor yang Berhubungan dengan Pemilihan Tenaga Penolong Persalinan di Wilayah Kerja Puskesmas Jelbuk Kabupaten Jember (Tesis).FKM-UI.Depok.

Murti B (2013). Desain dan Ukuran Sampel untuk Penelitian Kuantitatif dan Kualitatif di Bidang Kesehatan. Yogyakarta: Gajah Mada University Press

Nakambale A, Nzala S, Hazemba A (2014). Medical Journal of Zambia: Factors Affecting Utilization of Skilled Birth Attendants by Women in Northern Zambia, 41(2):86-94.

Prasetyawati A (2012). Kesehatan Ibu dan Anak (KIA) dalam Millenium Development Goals (MDG'S).Nuha Medika.Yogyakarta.

Riset Kesehatan Dasar (Riskesdas) (2013). Badan Penelitian dan Pengembangan Kesehatan Kementerian RI tahun 2013. Jakarta.

Sumintardi C (2012).Determinan Pemilihan Penolong Persalinan di Wilayah Kerja Puskesmas Kalibunder Kabupaten Sukabumi Tahun 2011-2012 (Tesis) FKM-UI.Depok.

Tadese F, Ali A (2014). Determinants of Use of Skilled Birth Attendance Among Mothers Who Gave Birth in the Past 12 months in RayaAlamata 
Journal of Health Promotion and Behavior (2017), 2(2): 161-174

https://doi.org/10.26911/thejhpb.2016.02.02.06

District. North East Ethiopia, Clinics Mother Child Health 11: 164. doi: 10.4172/ 2090-7214.1000164

WHO (2016). Standards For Improving Quality Of Maternal and Newborn Care In Health Facilities.Geneva Switzerland.

World Health Organization (WHO)(2004). Making Pregnancy Safer: The Critical Role of The Skilled Attendant: A joint Statement by WHO.ICM and FIGO. Geneva.

Yenita (2011). Faktor Determinan Pemilihan Tenaga Penolong Persalinan Di Wilayah Kerja Puskesmas Desa Baru
Kabupaten Pasaman Barat (Tesis). FKM-Universitas Andalas Padang. Yoshimura Y, Tajul M, Nazrul I (2014). Practices And Determinants Of Delivery By Skilled Birth Attendants In Bangladesh. Reproductive Health 11:86.

(2007).Survei Demografi dan Kesehatan Indonesia 2007. Jakarta. Indonesia.

(2016). The Sustainable Development Goals Report 2016. United Nations. New York. (2012).Survei Demografi dan Kesehatan Indonesia 2012. Jakarta 